\title{
In vitro and in vivo anthelmintic activity of extracts from Artemisia parviflora and $A$. sieversiana
}

\section{S. IRUM ${ }^{1,5}$, H. AHMED ${ }^{2,7}$, B. MIRZA ${ }^{3}$, K. DONSKOW-ŁYSONIEWSKA ${ }^{4,6}$, A. MUHAMMAD', M. QAYYUM ${ }^{4}$, S. SIMSEK ${ }^{7 *}$}

\begin{abstract}
1Department of Zoology/Biology, Arid Agriculture University Rawalpindi, Rawalpindi, Pakistan; ${ }^{2}$ Department of Biosciences, COMSATS Institute Of Information Technology (CIIT), Park Road, Chakh Shahzad, Islamabad, Pakistan; ${ }^{3}$ Department of Biochemistry, Quaid-e-Azam University, Islamabad, Pakistan; " ${ }^{2}$ aboratory of Parasitology, General Karol Kaczkowski Military Institute of Hygiene and Epidemiology, Warsaw, Poland; ${ }^{5}$ Department of Zoology, University of Gujrat, Gujrat Pakistan; ${ }^{6}$ Department of Parasitology, Institute of Zoology, Faculty of Biology, University of Warsaw, Poland; ${ }^{7 *}$ Department of Parasitology, Faculty of Veterinary Medicine, University of

Firat, 23119, Elazig-Turkey, E-mail: ssimsek@firat.edu.tr
\end{abstract}

Article info

Received January 9, 2017 Accepted April 19, 2017

\begin{abstract}
Summary
In the northern areas of Pakistan, the use of Artemisia based therapeutics is a common practice. Plants of genus Artemisia are known to possess anthelmintic and therapeutic effect. Infections caused by gastrointestinal nematodes are major threat to livestock industry across the world resulting in loss of production and indirect economic losses due to high cost of anthelmintic drugs. Present study was carried out to evaluate in vitro and in vivo effect of Artemisia sieversiana and Artemisia parviflora on Haemonchus contortus, a parasitic nematode of small ruminants. Methanolic plant extract was tested against three different developmental stages using an egg hatch assay, infective larvae and adult worm motility assay. Different concentrations were used for the bioassays and post exposure mortality was recorded after $8 \mathrm{hr}$ for adult worms and infective larvae, while egg inhibition percentage was observed after $27 \mathrm{hr}$. A highly significant ability to inhibit the egg hatching (100\%) was recorded for both plant extracts while, the highest activity for adult worm assay and larvicidal assay was $90 \%$ for $A$. sieversiana. The highest activity for adult motility and larvicidal assay for $A$. parviflora was $89 \%$ and $86.6 \%$ respectively. For in vivo trials maximum parentage reduction was $77.0 \%$ for A. sieversiana and $73.6 \%$ for A. parviflora. It is concluded that selected plant extracts were effective in reducing worm burden in animals.
\end{abstract}

Keywords: Artemisia parviflora; Artemisia sieversiana; plants; Anthelmintics; Haemonchus contortus

\section{Introduction}

Infections caused by gastrointestinal nematodes are major threat to livestock industry in the developing countries. They cause direct effects in form of loss in production and indirect economic losses due to high cost of anthelmintic drugs (Kassai, 1999). Various strategies are in practice to control parasitism which includes pasture management, biological control, dietary management, vaccination and use of anthelmintic drugs (FAO, 2002). Widely and most common practice being followed these days is the use of chemical anthelmintics (Muhammad et al., 2015). The intensive use has posed a variety of problems including emergence of anthelmintic resistance, e.g. multi resistant $H$. contortus had been already isolated. In addition, commercially available anthelmintics are relatively expensive and smallholder farmers are unable to spend meager income for purchase of drugs to continue regular treatment (Chandrawathani et al., 2003; Waller \& Thamsborg, 2004). The aforementioned points hint for a quest for suitable (natural and cheap) alternatives.

\footnotetext{
$\overline{{ }^{*} \text { - corresponding author }}$
} 
Plant products have potential of curing various ailments including parasitism. A number of plant species have been used and reported in different parts of world against nematode infections in animals and humans (Akhter et al., 2000). In Pakistan also a huge proportion of farmers rely on plants as a control strategy for the treatment of helminthosis. Various plants have been scientifically validated for their anthelmintic property both in vitro and in vivo (lqbal et al., 2005; 2006; 2007; Irum et al., 2015).

Many researchers reported the used of different plant species to control the parasitic infestation in sheep which are effective alternatives to conventional anthelmintics (Githiori et al., 2006). Plants of genus Artemisia are known to possess anthelmintic and therapeutic effects (Irum et al., 2015). Quite a few species are already reported to possess anthelmintic properties such as Artemisia annua L. extracts (Cala et al., 2014). In Northern areas of Pakistan, the use of Artemisia based treatment is also common practice. The indigenous people in Ranyan hills (Shangla, KPK, Pakistan) are reported to possess knowledge to use Artemisia species for a number of medicinal purposes (Ibrar et al., 2007). Similarly, it has been reported that $A$. scopariaisa purgative and also used to treat burns in Tehsil Pindi gheb, District Attock Pakistan (Hayat et al., 2008). A. brevifolia was found as an anthelmintic and also used for stomach problems in Kurram Agency, Pakistan (Gilani et al., 2003). Additionally A. maritima and A. brevifolia have been found to be used against abdominal pain, fever and intestinal worms in Chitral valley (Aziz, 1996).

In this article we reported in vitro and in vivo anthelmintic activity of crude methanolic extracts of $A$. siversiana and $A$. parviflora against gastrointestinal nematodes of sheep. The present study was first time conducted on Artemisia spp. (A. siversiana and A. parviflora) of study area as an antihelimenthics against Haemonchus spp.

\section{Materials and Methods}

\section{Plant material}

Plants were collected from northern areas of Pakistan. Species were identified by botanist in Quaid e-Azam University, Islamabad and voucher specimen of $A$. parviflora Buch.-Ham.and A. siversiana var. (cat. N. 26, 30). They were dried in shade and ground to fine powder. The powdered material was mixed with $70 \%$ methanol ( $2 \mathrm{~kg}$ dry weight in $1 \mathrm{~L}$ of methanol) and left for 3 days. Mixtures were filtered using muslin cloth and same process was repeated three times to obtain maximum amounts of plant extract. Finally, filtrate was concentrated in a rotary evaporator (yield: $11.5 \% \mathrm{w} / \mathrm{w}$ ) and stored at $-70^{\circ} \mathrm{C}$ until use.

\section{Larvicidal assay}

Larvicidal assay was conducted guidelines provided by WAAVP with slight modifications (Coles et al., 1992). To analyze the effect of different plant concentration on larvae of nematode, Baermann technique was used. For this purpose faecal samples were collected rectally from animals artificially infected with Haemonchus contortus using two finger method. The samples in plastic bags were transported to Parasitology Laboratory, Department of Biology/Zoology, and then samples were integrated to get a $15 \mathrm{~g}$ sample. A crumbly moist solution was obtained by crushing in mortar following addition of moister. Thereafter an equal quantity of vermiculate was added and solution was shifted to a glass beaker which was covered with a porus aluminium foil having $10-13$ small holes for aeration and incubated at room temperature for $12-14$ days. The infective $L_{3}$ larvae of $H$. contortus were obtained by crushing the female parasites in water to obtain eggs followed by culturing in fecal samples. $L_{3}$ larvae were obtained after 14 days through Baermann's apparatus. The faecal material was poured on cheese cloth over Baermann apparatus and left for 24 hours. "After 24 hours, L3 stages of the parasites were centrifuged (5 times 1000 rpm for 5 minutes) to concentrate, picked with micropipette and washed in PBS which were collected from the test tubes attached at the end of Baermann apparatus.

They were incubated with plant extracts at concentrations of 100 , $50,25,12.5,6.25,3.12$ and $1.56 \mathrm{mg} / \mathrm{ml}$ of PBS (pH 7.2) in triplicates, PBS alone was used as a negative control and ivermectin $0.01 \mathrm{mg} / \mathrm{ml}$ was used as positive control. Mortality of larvae subjected to above treatments was used as a criterion for anthelmintic activity. The motility, and hence mortality, was recorded after 0 , $1,2,3,4$, and up to $8 \mathrm{hr}$. Post- treatment revival of motility was observed by keeping the treated worms in PBS for 30 min. Three replications were used for each concentration of plant extract.

\section{Adult worm assay}

Adult worms of $H$. contortus were collected from abomasum of sheep soon after slaughtering. The parasites were washed in PBS. Then from these washed parasites, actively moving of ten worms were selected and placed in the Petri dishes $(74 \mathrm{~mm}$ base diameter) filling with different concentrations $(100,50,25,12.5$, 6.25 and $3.12 \mathrm{mg} / \mathrm{mL}$ ) plants (A. parviflora and $A$. seversiana) methanolic extracts in PBS at $37^{\circ} \mathrm{C}$ and three replications were used for each treatment. Ivermectin was used as a positive control and PBS alone was used as negative control. Three replication for each treatment (each concentration of drug/extract) were employed. After 8 hours, possible parasite motility was checked by suspending parasites in PBS for 30 min after washing away extract and positive control and under dissecting microscope, alive (motile) and dead (immotile) worms were counted and recorded in each concentration. Moreover, lack of motility for of $5-6$ seconds and by touching the parasite is suspected as death or paralysis of worms.

\section{Egg hatch assay}

The egg hatch assay was performed as per Coles et al. (1992) with some modifications. Adult female $H$. contortus worms were crushed in PBS with pestle and mortar. The mixture was passed 
through fine sieve and number of eggs was counted and adjusted 250 eggs/ml (approximately). Plant extract with concentrations of $100,50,25,12.5,6.25,3.12$ and $1.56 \mathrm{mg} / \mathrm{ml}$ was used along with positive and negative controls. Three repetitions were used for each concentration using $27 \mathrm{hrs}$ incubation times with $37^{\circ} \mathrm{C}$.

\section{In vivo studies}

Treatment and follow-up procedures

In vivo trial was conducted at Barani Livestock Production Institute Kharimurat Punjab, Pakistan approved for research purpose as letter no (PMAS-AAUR/ ZOOL/592). Experimental designs included 30 sheep (each group) ranging 8 - 12 months, $18-24 \mathrm{~kg}$ in weight and were placed in 6 groups. Animal de-worming was carried out by mean of levamisole (Levasolß $7.5 \mathrm{mg} / \mathrm{kg}, \mathrm{ICl}$, Pakistan), kept indoor for 20 days and infected orally with approximately $5000 \mathrm{H}$. contortus. Twenty days later, number of eggs per gram of feces (EPG) in each animal was counted by the modified McMaster technique. On same day, all sheep were weighed, identified by ear tags and randomly assigned to six treatment groups (for all selected plant extracts) $(n=5)$ and orally treated. The animals having higher than 5000 eggs per gram were included in experiment. The groups numbers assigned according to plant extract administered as oral dose by gavage [dissolved in Dimethyl Sulfoxide (DMSO) diluted in PBS] were as follows:
Group l: $\quad 50 \mathrm{mg} / \mathrm{kg}$ body weight
Group II: $\quad 25 \mathrm{mg} / \mathrm{kg}$ body weight
Group III: $\quad 12.5 \mathrm{mg} / \mathrm{kg}$ body weight
Group IV: $\quad 6.25 \mathrm{mg} / \mathrm{kg}$ body weight
Group V: $\quad$ Negative control, untreated (distilled water)
Group Vl: $\quad$ Positive control, levamisole
(Levasol, $7.5 \mathrm{mg} / \mathrm{kg}, \mathrm{ICl}$, Pakistan)

\section{Fecal Egg Count Reduction Test (FECRT)}

Initial FEC (Fecal Egg Count), body weight, FAMACHA score and blood samples were taken prior to experiment. After treatment fecal samples were collected directly from rectum on a weekly basis for 4 weeks and stored in zip lock bags for laboratory analysis. Blood was drawn at the same time from the jugular vein into EDTA-coated vacutainers (Bectan, Dickinson, India). Aliquots of 2 gram of fecal sample were mixed with saturated sodium chloride salt solution, homogenized as recommended in sedimentation and floatation method and observed on slide using an Olympus B 201 microscope and observed on slide using an Olympus B 201 micro-

Table 1. In vitro effect of methanolic extract of $A$. parviflora and $A$. siversiana on $H$. contortus adult and $\mathrm{L}_{3}$ stages. Mean efficacy (Mortality $\pm \mathrm{S}$.E) of methanol extracts of $A$. parviflora and $A$. siversiana on egg hatching. Results represent the mean $\pm \mathrm{SE}$ of the samples.

\begin{tabular}{|c|c|c|c|c|c|c|c|}
\hline \multirow[t]{2}{*}{$\begin{array}{l}\text { Plant } \\
\text { name }\end{array}$} & \multirow[t]{2}{*}{$\begin{array}{l}\text { Concentrations } \\
\qquad(\mathrm{mg} / \mathrm{ml})\end{array}$} & \multicolumn{3}{|c|}{$\begin{array}{l}\text { In vitro effect of methanolic extracts on different stages } \\
\qquad \text { Mortality } \pm \text { Standard Error (S.E) }\end{array}$} & \multicolumn{3}{|c|}{$\begin{array}{l}\text { Lethal concentration } 50\left(\mathrm{LC}_{50}\right) \text { for different } \\
\text { stages of Haemonchus }\end{array}$} \\
\hline & & Adult & $\mathrm{L}_{3}$ & $\begin{array}{l}\text { Egg hatching } \\
\qquad \mu \mathrm{g} / \mathrm{ml}\end{array}$ & Adult & $\mathrm{L}_{3}$ & Egg hatching \\
\hline \multirow{9}{*}{ 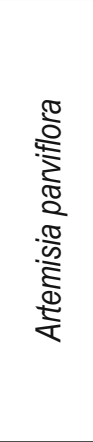 } & 100.0 & $86.6 \pm 2.20$ & $89.9 \pm 0.78$ & $99.6 \pm 0.33$ & \multirow{9}{*}{$9.02 \mathrm{mg} / \mathrm{ml}$} & \multirow{9}{*}{$5.18 \mathrm{mg} / \mathrm{ml}$} & \multirow{9}{*}{$5.12 \mu \mathrm{g} / \mathrm{ml}$} \\
\hline & 50.0 & $70.0 \pm 1.72$ & $83.3 \pm 0.69$ & $94.0 \pm 2.08$ & & & \\
\hline & 25.0 & $73.3 \pm 1.47$ & $59.9 \pm 0.22$ & $88.3 \pm 0.88$ & & & \\
\hline & 12.5 & $63.3 \pm 1.35$ & $53.3 \pm 0.37$ & $85.3 \pm 0.33$ & & & \\
\hline & 6.25 & $40.0 \pm 0.71$ & $33.3 \pm 0.24$ & $77.0 \pm 1.52$ & & & \\
\hline & 3.12 & $23.3 \pm 0.47$ & $23.3 \pm 0.19$ & $51.6 \pm 1.66$ & & & \\
\hline & 1.56 & $19.9 \pm 0.47$ & $16.6 \pm 0.14$ & $63.6 \pm 1.66$ & & & \\
\hline & Ivermectin & $99.0 \pm 0.33$ & $99.0 \pm 0.33$ & $97.0 \pm 1.0$ & & & \\
\hline & PBS & $0.33 \pm 0.20$ & $1.30 \pm 0.20$ & $25.0 \pm 7.1$ & & & \\
\hline \multirow{9}{*}{ 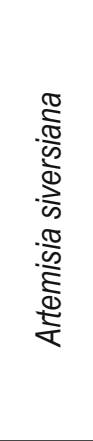 } & 100.0 & $89.9 \pm 1.22$ & $90.0 \pm 0.71$ & $100.0 \pm 00$ & \multirow{9}{*}{$8.37 \mathrm{mg} / \mathrm{ml}$} & \multirow{9}{*}{$5.02 \mathrm{mg} / \mathrm{ml}$} & \multirow{9}{*}{$5.38 \mu \mathrm{g} / \mathrm{ml}$} \\
\hline & 50.0 & $83 . .3 \pm 0.88$ & $73.0 \pm 0.58$ & $96.33 \pm 1.33$ & & & \\
\hline & 25.0 & $66.58 \pm 0.47$ & $66.0 \pm 0.30$ & $86.66 \pm 1.66$ & & & \\
\hline & 12.5 & $49.9 \pm 0.36$ & $46.0 \pm 0.19$ & $78.38 \pm 1.66$ & & & \\
\hline & 6.25 & $37.0 \pm 0.22$ & $40.0 \pm 0.14$ & $68.33 \pm 4.40$ & & & \\
\hline & 3.12 & $29.9 \pm 0.12$ & $26.0 \pm 0.14$ & $58.33 \pm 1.66$ & & & \\
\hline & 1.56 & $23.3 \pm 0.16$ & $19.9 \pm 0.13$ & $33.3 \pm 1.66$ & & & \\
\hline & Ivermectin & $99.0 \pm 0.33$ & $99.0 \pm 0.33$ & $97.0 \pm 1.00$ & & & \\
\hline & PBS & $0.33 \pm 0.20$ & $1.30 \pm 0.20$ & $25.0 \pm 0.20$ & & & \\
\hline
\end{tabular}


scope (Optical Element Corporation, Melville, USA) at 100× magnification. Number of eggs counted on Mc Master Chambers was multiplied by 50 to obtain EPG. Fecal egg count reduction (FECR) percentage was calculated using the formula ECR (Egg Count Reduction) $(\%)=$ EPG prior to treatment- EPG post-treatment/EPG (prior to treatment) $\times 100$

\section{Statistical analysis}

Statistical analyses were performed using the SPSS17 software (SPSS Institute, USA). Tests of the significance of factors on parasite mortality were conducted by analysis of variance (ANOVA). Differences were considered significant at $P<0.05$. Determination of $\mathrm{LC}_{50}$ was done using regression analysis solving the regression equation by graphical method. Mean with significance were compared with Least Significant Differences (LSD) test using SPSS software.

\section{Results}

The mean efficacy percentage \pm S.E. of $A$. siversiana and $A$. parviflora on $H$. contortus for adult worm motility/mortality assay is shown in Table 1. There was a significant $(P<0.05)$ dose and time dependent response for both extracts. Maximum reduction of motility for adult motility/mortality assay was recorded to be $86.6 \%$ and $89.9 \%$ at $100 \mathrm{mg} / \mathrm{ml}$ for $A$. parviflora and $A$. siversiana, respectively. The lowest activity for $A$. parviflora was $19.9 \%$ while $A$. siversiana showed $23.3 \%$. There was a gradual decrease observed in mortality with decreasing concentrations. LC50 value for $A$. parviflora was $9.02 \mathrm{mg} / \mathrm{ml}$ while for $A$. siversiana it was recorded to be $8.37 \mathrm{mg} / \mathrm{ml}$ almost all worms were found dead for ivermectin treated group $8 \mathrm{hr}$ post treatment.

The results for efficacy of extracts on infective larvae are represented in Table 1. The best efficacy was $89.9 \%$ for A.parviflora while it was $90 \%$ for $A$. siversiana. Lowest activity of $16.6 \%$ was recorded for A. parvifloria and $19.9 \%$ for $A$. siversiana at 1.56 $\mathrm{mg} / \mathrm{ml}$. While, other concentrations used also showed significant decrease in the number of infective larvae with course of time. The activity of plant extracts on egg hatching is shown in Table 1. It is evident from results that methanolic extracts demonstrated in vitro anthelmintic activity on egg hatching. A. parviflora showed maximum activity of $99.6 \%$ having $\mathrm{LC}_{50}$ of $5.12 \mathrm{mg} / \mathrm{ml}$ while lowest activity remained to be $63.6 \%$. For $A$. siversiana $100 \%$ activity was observed at $100 \mathrm{mg} / \mathrm{ml}$ whereas lowest remained to be $33.3 \%$ $\mathrm{LC}_{50}$ was $5.02 \mathrm{mg} / \mathrm{ml}$. The results for in vitro trials showed there was significant activity to reduce worm burden.

In vivo results of fecal egg counts for $A$. siversiana showed reductions in EPG concentrations by the $2^{\text {nd }}$ week after treatment as $77 \%$ in first group followed by $69.0 \%, 62.70 \%$ and $58.27 \%$ in groups II, III and IV, respectively (Table 2). While A. parviflora showed maximum reduction of $73.63 \%$ in group I followed by $69.76 \%, 58.25 \%$, and $30.04 \%$ in groups II, III and IV (Table 3). In control group treated with water FEC remained almost steady with certain fluctuations throughout period of observation. The values for PCV and FAMACHA also showed slight variation during course of study before and after treatment. For $A$. siversiana group I (50 $\mathrm{mg} / \mathrm{mL}$ ) showed PCV to be $22 \%$ followed by $25.50 \%, 31.5 \%$ and $26.5 \%$ in groups II, III and IV, respectively. While for $A$. parviflora it remained $28 \%$ at end of trial with variations during each week after drug administration.

\section{Discussion}

The results for anthelmintic activity of $A$. siversiana and $A$. parviflora exhibited promising effects also on adult stages of nematodes at different concentrations in a dose dependent manner. The highest activity for adult motility assay for $A$. parviflora and $A$. servisiana $(86.6 \%$ and $90 \%)$ are in agreement with methanolic extracts used against $H$. contortus (Iqbal et al., 2004). The methanolic extract of $A$. siversiana exhibited $100 \%$ inhibition in hatching of eggs at $50 \mathrm{mg} / \mathrm{ml}$ and $99 \%$ hatching was inhibited at same concentration

Table 2. Mean FEC $\pm S E$ in sheep treated with different concentrations of $A$. siversiana along with negative and positive control.

Group I: Crude Methanolic Extract (CME) at $50 \mathrm{mg} / \mathrm{kg}$ body weight (b.w.); II: CME at $25 \mathrm{mg} / \mathrm{kg}$ b.w.; III: CME at 12.5 mg/kg b.w.; IV: CME at $6.25 \mathrm{mg} / \mathrm{kg}$ b.w.; V: Negative control, untreated (PBS, 7.2); VI: Positive control, levamisole (Levasol $($, ICl, Pakistan) at 7.5 mg/kg b.w.

\begin{tabular}{|c|c|c|c|c|c|c|}
\hline \multirow{2}{*}{ Groups } & \multicolumn{5}{|c|}{ Weeks (W) } & \multirow{2}{*}{$\begin{array}{l}\% \text { egg } \\
\text { reduction }\end{array}$} \\
\hline & Day 0 & $W_{1}$ & $W_{2}$ & $W_{3}$ & $W_{4}$ & \\
\hline I & $1475 \pm 25.07^{a}$ & $1162.75 \pm 62.93^{a}$ & $1012.5 \pm 12.53^{a}$ & $912.5 \pm 12.53^{a}$ & $612.5 \pm 112.83^{a}$ & 77.00 \\
\hline ॥ & $1362.5 \pm 62.68^{b}$ & $1175.0 \pm 25.0^{b}$ & $975 \pm 25.00^{b}$ & $787.50 \pm 25.0^{b}$ & $612.0 \pm 87.76^{b}$ & 69.00 \\
\hline III & $1025 \pm 25.07^{\mathrm{ab}}$ & $2075 \pm 25.07^{\mathrm{ab}}$ & $1400 \pm 150.40^{\mathrm{bc}}$ & $975 \pm 275.80^{\mathrm{bc}}$ & $850 \pm 175.50^{\mathrm{ac}}$ & 62.70 \\
\hline IV & $875.5 \pm 25.07^{c}$ & $762.50 \pm 37.07^{\mathrm{ab}}$ & $587.5 \pm 37.61^{c}$ & $412.5 \pm 37.61^{c}$ & $325.0 \pm 25.07^{c}$ & 58.27 \\
\hline V & $3000 \pm 52.10^{c}$ & $2966 \pm 60.14^{c}$ & $2946 \pm 62.90^{d}$ & $2925 \pm 62.90^{d}$ & $2905 \pm 45.05^{d}$ & - \\
\hline VI & $1650 \pm 180.49^{d}$ & $1050 \pm 76.40^{d}$ & $700 \pm 115.60^{e}$ & $366.6 \pm 49.10^{\mathrm{e}}$ & $183.33 \pm 44.10^{\mathrm{e}}$ & - \\
\hline
\end{tabular}

FEC: Fecal Egg Count

${ }^{*}$ Small letters compare means in row. Different letters indicate significantly different values $(P<0.05)$. 
Table 3. Mean FEC $\pm S E$ in sheep treated with different concentrations of $A$. parviflora along with negative and positive control. Group I: Crude Methanolic Extract (CME) at $50 \mathrm{mg} / \mathrm{kg}$ body weight (b.w.); II: CME at $25 \mathrm{mg} / \mathrm{kg}$ b.w.; III: CME at $12.5 \mathrm{mg} / \mathrm{kg}$ b.w.; IV: CME at $6.25 \mathrm{mg} / \mathrm{kg}$ b.w.; V: Negative control, untreated (PBS, 7.2); VI: Positive control, levamisole (Levasol ${ }^{\circ}, \mathrm{ICI}$, Pakistan) at $7.5 \mathrm{mg} / \mathrm{kg}$ b.w.

\begin{tabular}{|c|c|c|c|c|c|c|}
\hline \multirow{2}{*}{ Groups } & \multicolumn{5}{|c|}{ Weeks (W) } & \multirow{2}{*}{$\begin{array}{l}\% \text { egg } \\
\text { reduction }\end{array}$} \\
\hline & Day 0 & $W_{1}$ & $\mathrm{~W}_{2}$ & $W_{3}$ & $W_{4}$ & \\
\hline 1 & $2086 \pm 486.80^{f}$ & $1850.75 \pm 300.8^{f}$ & $1525.5 \pm 25.27^{f}$ & $962.5 \pm 37.61^{f}$ & $550.5 \pm 50.14^{f}$ & 73.63 \\
\hline ॥ & $2150.5 \pm 150.4^{g}$ & $1525.0 \pm 25.0^{9}$ & $1225 \pm 25.07^{9}$ & $787.50 \pm 25.0^{9}$ & $650.0 \pm 50.14^{g}$ & 69.76 \\
\hline III & $1677 \pm 22.56^{\mathrm{fg}}$ & $1237 \pm 87.76^{\text {fg }}$ & $1050 \pm 150.40^{g h}$ & $950 \pm 50.14^{9 h}$ & $700 \pm 100.28^{\text {th }}$ & 58.25 \\
\hline IV & $1222.5 \pm 25.07^{h}$ & $1212.50 \pm 25.07^{\mathrm{fg}}$ & $1025 \pm 37.67^{h}$ & $937.5 \pm 12.53^{h}$ & $850.0 \pm 50.07^{\mathrm{h}}$ & 30.04 \\
\hline V & $3000 \pm 52.10^{\mathrm{h}}$ & $2966 \pm 60.14^{h}$ & $2946 \pm 62.90^{\circ}$ & $2925 \pm 62.90^{\circ}$ & $2905 \pm 45.05^{j}$ & - \\
\hline VI & $1650 \pm 180.49$ & $1050 \pm 76.40^{\mathrm{j}}$ & $700 \pm 115.60^{k}$ & $366.6 \pm 49.10^{k}$ & $183.33 \pm 44.10^{k}$ & - \\
\hline
\end{tabular}

FEC: Fecal Egg Count

*Small letters compare means in row. Different letters indicate significantly different values $(P<0.05)$.

for A. parviflora. Similar results have been reported for activity of Spigellea anthelmia inhibiting $100 \%$ hatching and $81.2 \%$ of larval development at $50 \mathrm{mg} / \mathrm{ml}$ (Assis et al., 2003), anthelmintic activity of $A$. indica and $A$. roxburghiana against mixed nematodes (Khan et al., 2015) and $A$. vestita and $A$. maritime (Irum et al., 2015). The highest larvicidal activity was $89.9 \%$ and $90 \%$ for $A$. parviflora and A. siversiana, respectively, which correspond to reported activity of Melia azedarach on $H$. contortus infective larvae which exhibited $87.4 \%$ and $95.7 \%$ mortality, respectively (Maciel et al., 2006). The motility was $100 \%$ of $A$. mexicana. The $\mathrm{LC}_{50}, \mathrm{LC}_{90}$ and $\mathrm{LC}_{99}$ to $A$. mexicana was 92.85, 210.44 and $410.04 \mathrm{mg} / \mathrm{L}$ (Alvarez- Mercado et al., 2015). Similar observations were reported by Nawaz et al. (2014) that plant extracts (Azadirachta indica, Dalbergia sisso and Morus alba) induced $89 \%, 87 \%$ and $36 \%$ reduction in EPG.

In vivo anthelmintic activities correspond with previous studies exhibited by various plant extracts. Hafiz et al. (2009) reported maximum ECR $87.3 \%$ exhibited by the crude methanolic extract of $T$. arjuna bark applying $3 \mathrm{~g}$ per $\mathrm{kg}$ on day 11 post treatment followed by crude powder which showed $50 \%$ in vivo activity when applied $2 \mathrm{~g}$ per $\mathrm{kg}$ of body weight. Similar results were also found in present study in which maximum reduction of $77 \%$ is recorded $A$. siversiana post treatment. In vivo efficiency of aqueous extract of higher dose of Coriandrum sativum on Haemonchus showed activity of $25.56 \%$ maximum reduction in worm count (Athanasiadou et al., 2001). This activity is much lower than activity exhibited by A. parviflora $73.63 \%$ thus showing effectiveness in controlling worm burden.

It has been reported that transcuticular diffusion accounts for entry of non-nutrient and non-electrolyte substances into helminth parasites. Furthermore, it has been described as the major route for the uptake of broad spectrum anthelmintics by different nematodes, trematodes and cestodes as compared to oral ingestion (Geary et al., 1998). Additionally, anthelmintic activity of $A$. siversiana and A. parviflora can also be attributed to presence of different metabolites including alkaloids, flavonoids and terpenoids which are among the active biological compounds present in plants. Several studies have been conducted demonstrating effect of various biologically active compounds and their anthelmintic activity as $A$. annua is reported to have alkaloids, flavoids and polyphenols (Ajah et al., 2010). Also, chemical analysis of extracts from M. azedarachta fruit revealed presence of tannins, phenolic compounds and steroids (Danticiacao et al., 2000) while presence of terpenoids has been detected in various plants having anthelmintic activity (Athanasiadou et al., 2001).

Based on in vitro tests for anthelmintic activity, $A$. siversiana and $A$. parviflora it can be considered as promising tools to reduce worm burdens in animals. Both plants exhibited significant $(P<0.05)$ dose and time dependent in vivo anthelmintic activity on gastrointestinal nematodes. An experiment was conducted to evaluate in vivo anthelmintic activity of $A$. indica using a faecal egg count reduction test in sheep naturally infected with helminths. Our findings are in accordance with Nawaz et al. (2014). Maximum reduction (98.9\%) was observed with CAME (Al-Shaibani et al., 2009). In vivo anthelmintic activity exhibited by $A$. parviflora at $50 \mathrm{mg} /$ $\mathrm{kg}$ and $25 \mathrm{mg} / \mathrm{kg}$ of body weight $(73.63 \%$ and $69.76 \%)$ are in agreement with Al-Shaibani et al. (2009), who have evaluated anthelmintic efficacy of $F$. parviflora in an in vivo trail which revealed that experimental animal groups treated with doses of $200 \mathrm{mg} / \mathrm{kg}$ of either aqueous or ethanolic extracts of $F$. parviflora exhibited higher $(P<0.05)$ reduction rates on fecal egg counts as compared to un-treated groups (negative control). Highest reduction rate on FEC of treated animal groups was recorded as $77.6 \%$ and $70.05 \%$ with ethanolic and aqueous extracts, respectively at 200 $\mathrm{mg} / \mathrm{kg}$ on day 14 post treatment, whereas using 50 and $100 \mathrm{mg} /$ $\mathrm{kg}$ as treatment doses, result in reduction rate ranging between $3.79 \%$ to $61.45 \%$ from day $3-14$ post treatment. Artemisia parviflora exhibited almost similar activity at $50 \mathrm{mg} / \mathrm{kg}$ of body weight of animal.

Thus, it is concluded that plant extracts possess potential anthelmintic activity and there is a need to explore and scientifically val- 
idate vital components in form of secondary metabolites present in important plant species. Moreover, plant extracts can also act as important substitutes to synthetic anthelmintic drugs which are generating anthelmintic resistance.

\section{Acknowledgements}

The authors are grateful to Higher Education Commission (HEC) of Pakistan for providing financial support to conduct in vitro trials at PMAS- Arid Agriculture University. Thanks to the Department of Biochemistry, Quaid-e-Azam University Islamabad for preparing plant extracts. Also special thanks to Barani Livestock Station Kharimurat for providing facility for the in vivo study. We are very thankful to TUBITAK (2216-research fellowship program for international researchers) to provide an opportunity and funding to work for Dr. Haroon Ahmed.

\section{Conflict of Interest}

Authors declare no conflict of interest regarding originality of this work.

\section{References}

Athanasiadou, S., Kyriazakis, I., Jackson, F., CoOp, R.L. (2001): Direct anthelmintic effects of condensed tannins towards different gastrointestinal nematodes of sheep: in vitro and in vivo studies. Vet. Parasitol., 99: 205 - 19. DOI: 10.1016/S0304-4017(01)00467-8

AJah, P.O., ETEng, M.U. (2010): Phytochemical screening and histopathological effects of single acute dose administration of Artemisia annua L. on testes and ovaries of Wistar rats. Afr. J. Biochem. Res., 4:179 - 185.

Alvarez-Mercado, J.M., Ibarra-Velarde,F., Alonso-Díaz, M.A., Vera-Montenegro, Y., Avila-Acevedo,J.G., García-Bores,A.M. (2015): In vitro antihelmintic effect of fifteen tropical plant extracts on excysted flukes of Fasciola hepatica. BMC Vet. Res., 11, 45. DOI:10.1186/s12917-015-0362-4

AkHtar, M.S., Iqbal Z., Khan, M.N., Lateef, M. (2000): Anthelmintic activity of medicinal plants with particular reference to their use in animals in Indo-Pakistan subcontinent. Small. Rum. Res., 38, 99 107. DOI: 10.1016/S0921-4488(00)00163-2

Alawa, C.B.I., Adamu, A.M., Gefu, J.O., Ajanusi, O.J., Abdu, P.A., Chiezey, N.P., AlaWA, J.N., Bowman, D.D. (2003): In vitro screening of two Nigerian medicinal plants (Vernonia amygdalina and Annona senegalensis) for anthelmintic activity. Vet. Parasitol., 113, 73 - 81. DOI: 10.1016/S0304-4017(03)00040-2

Al-Shaibani, I.R.M., Phulan, M.S., ShiekH, M. (2009): Anthelmintic activity of Fumaria parviflora (Fumariaceae) against gastrointestinal nematodes of sheep. Int. J. Agri. Biol., 11, 431 - 436

Assis, L.M., Bevilaqua, C.M.L., Morais, S.M., VieiRa, L.S., Costa, C.T.C., SouzA, J.A.L. (2003): Ovicidal and larvicidal activity in vitro of Spigelia anthelmia Linn extracts on Haemonchus contortus. Vet.
Parasitol., 117, 43 - 49. DOI:10.1016/j.vetpar.2003.07.021

Athanasiadou, S., Kyriazakis, I., Jackson, F., CoOp, R.L. (2001): Direct anthelmintic effects of condensed tannins towards different gastrointestinal nematodes of sheep: in vitro and in vivo studies. Vet. Parasitol., 99: 205 - 219. DOI: 10.1016/S03044017(01)00467-8

Azız, A. (1996). Indigenous knowledge of plant uses and ethnobotany of Chitral with particular reference to medicinal plants. In Proceedings of the Ethnobotany Workshop, National Agriculture Research Center, Islamabad.

BaChaya, H.A., IqBal, I., Khan, M.N., JabBar, A., GILANI, A.H., Din, I.U. (2001): In vitro and in vivo anthelmintic activity of Terminalia arjuna bark. Int. J. Agri. Biol., 11: 273 - 278

Chandrawathani, P., Jamnah, O., Waller, P.J., Larsen, M., Gillespie, A.T., ZAHARI, W.M. (2003): Biological control of nematode parasites of small ruminants in Malaysia using the nematophagous fungus Duddingtonia flagrans. Vet. Parasitol., 117: 173 - 183. DOI: 10.1016/j.vetpar.2003.08.005

Coles, G.C., Bauer, C., Borgsteede, F.H.M., Geerts, S., Klel, T.R., TAYLOR, M.A., Waller, P.J. (1992): World Association for the Advancement of Veterinary Parasitology (W.A.A.V.P.) methods for the detection of anthelmintic resistance in nematodes of veterinary importance. Vet. Parasitol., 44: 35 - 44

Cala, A.C., Ferreira, J.F., Chagas, A.C., Gonzalez, J.M., Rodrigues, R.A., Foglio, M.A., Oliveira, M.C., Sousa, I.M., Magalhães, P.M., BARIONIJÚNIOR, W. (2014): Anthelmintic activity of Artemisia annua L. extracts in vitro and the effect of an aqueous extract and artemisinin in sheep naturally infected with gastrointestinal nematodes. Parasitol. Res.,113: 2345 - 53. DOI: 10.1007/s00436-014-3891-z Dantciacao, D.A., Maganah, M., Beretta, T.E., Nozu, P., Pereira, G.S., Matias, R.S., Resende, U., Koller, W.W., Gomes, A. (2000): Study fitoquimico the fruits of Melia azedarach L. (Neem, Meliaceae). Encotro Research and Scientific Initiation of Uniderp, vol. 2, Uniderp, Campo Grande, MS. Anais, Campo Grande, pp. 118 120

FAO (2002): Biological control in a global perspective, a view on emphasis on Duddingtonia flagrans. Final Proceeding of FAO, Technical Co-operation Project in Malaysia. pp. 19 - 37

GithioRI, J.B., Athanasiadou, S., Thamsborg, S.M. (2006): Use of plants in novel approaches in control of gastrointestinal helminthes in livestock with emphasis on small ruminants. Vet. Parasitol., 139; 308 - 320. DOI: 10.1016/j.vetpar.2006.04.021

Geary, T.G., Nulf, S.C., Bowman, S.J.A., Mahmoud, B.M., Prichard, R.K., KLEIN, R. (1998): Cloning and characterization of cDNAs encoding beta-tubulin from Dirfilaria immitis and Onchocerca volvuIus. J. Parasitol., 84, $356-360$

Gilani, S.S., Abbas, S.Q., Shinwari, Z.K., Hussain, F., Nargis, K. (2003): Ethnobotanical studies of Kurram Agency, Pakistan through rural community participation. Pak. J. Biol. Sci., 6, 1368 - 1375 HAMmond, J.A.D., Fielding, BISHOP, S.C. (1997): Prospects for plant anthelmintics in tropical veterinary medicine. Vet. Res. Commun., 21, 213 - 228. DOI: 10.1023/A:1005884429253 
Hayat, M.Q., Khan, M.A., Ahmad, M., Shaheen, N, Yasmin, G., Akhter, S. (2008): Ethnotaxonomical approach in the identification of useful medicinal flora of Tehsil Pindigheb (District Attock) Pakistan. Ethnobot. Res. Applicat., 6; 35 - 62 DOI: 10.4314/ajtcam.v12i5.15 Irum, S., Ahmed, H., Mukhtar, M., Mushtaq, M., Mirza, B., DonSKOW-ŁysonieWSKA, K., QAYYUM, M., SimseK, S. (2015): Anthelmintic activity of Artemisia vestita Wall ex DC. and Artemisia maritima L. against Haemonchus contortus from sheep. Vet. Parasitol., 212; 451 - 455. DOI: 10.1016/j.vetpar.2015.06.02

IbraR, M., Hussanin, F., Sultan, A. (2007): Ethnobotanical studies on plant resources of Ranyal Hills, District Shangla, Pakistan. Pak. J. Bot., 39; 329 - 337

lqbal, Z., Sarwar M., Jabbar, A., Ahmed, S., Nisa, M., Sajid, M.S., Khan, M.N., MuftI, K.A., Yaseen, M. (2007): Direct and indirect anthelmintic effects of condensed tannins in sheep. Vet. Parasitol.,144; 125 - 131. DOI: 10.1016/j.vetpar.2006.09.035

lobal, Z., Lateef, M., Ashraf, M., Jabbar, A. (2004): Anthelmintic activity of Artemisia brevifolia in sheep. J. Ethnopharmacol., 93; 265 - 268. DOI: 10.1016/j.jep.2004.03.046

lqbal, Z., Lateef, M., JabBar, A., Muhammad, G., Khan., M.N. (2005): Anthelmintic activity of Calotropisprocera(Ait.) Ait. F. flowers in sheep. J. Ethnopharmacol., 102, 256 - 261. DOI:10.1016/j. jep.2005.06.022

lqbal, Z., Lateef, M., Jabbar A., Ghayur, M.N., Gilani, A. (2006): In vitro and In vivo anthelmintic activity of Nicotiana tabacum $\mathrm{L}$. leaves against gastrointestinal nematodes of sheep. Phytotherap. Res., 20, 46 - 48. DOI: 10.1002/ptr

KASSAI, T., 1999. Veterinary Helminthology. Reed educational and professional publishing Ltd., London pp. 196 - 197
Khan, S., Afshan, K., Mirza, B., Miller, J.E., Manan, A.,IRum, S., RIZVI, S.S., QAYYUM, M. (2015): Anthelmintic properties of extracts from Artemisia plants against nematodes. Trop. Biomed., 32: 257 $-268$

Maciel, M.V., Morals, S.M., Bevilaqua, C.M.L., Camurca-Vasconcelos, A.L.F., Costa, C.T.C., Castro, C.M.S. (2006): Ovicidal and larvicidal activity of Melia azedarach extracts on Haemonchus contortus. Vet. Parasitol., 140: 98 - 104. DOI: 10.1016/j.vetpar.2006.03.007

MAFF. (1979): Parasitological Laboratory Techniques Technical Bulletin No. 18. Ministry of Agriculture Fisheries and Food Manual of Veterinary. Her Majesty's Stationary Office, London. pp. 129

Muhammad, A., Ahmed, H., lqbal, M.N., Qayyum, M. (2015) Detection of multiple anthelmintic resistance of Haemonchus contortus and Teladorsagia circumcincta in sheep and goats of Northern Punjab, Pakistan. Kafkas. Univ. Vet. Fak. Derg., 21: 389 - 395. DOI: 10.9775/kvfd.2014.12581

Nawaz, M., Saudd, S.M., ZubaiR, M., Hussain, J., Abbası, Z., MoHi-UdDIN, A., WAQAS, M. (2014): In vitro and in vivo anthelmintic activity of leaves of Azadirachta indica, Dalbergia sisso and Morus alba against Haemonchus contortus. Global. Vet., 13: 996 - 1001. DOI: 10.5829/idosi.gv.2014.13.06.9154

Proksch, P. (1992): Artemisia. In: Hansel, R., Keller, K., Rimpler, H., Schneider, G. (Eds) Hager's Manual of Pharmaceutical Practice. Springer-Verlag, Berlin, pp. 357 - 377 (In German)

Waller, P.J., Thamsborg, S.M. (2004): Nematode control in green ruminant production systems. Trend. Parasitol., 20: 493 - 497. DOI: 10.1016/j/pt.2004.07.012 